\title{
LEGAL AID TO SOLDIERS IN THE BRITISH ARMY
}

\section{ERnst J. Cohn $†$}

In his article, "Lawyers and Morale", 1 Professor Bradway has drawn attention to the valuable services which the legal profession can render to the morale of the armed forces by giving free legal aid to serving men in those difficulties which arise out of their civilian life. Professor Bradway states that this requires action in four different directions, and adds that while substantial progress has already been made with the first two of these stages, too little has been done about the others. These two postulates which are still waiting to be transposed into reality are: ${ }^{2}$

(1) A supervising system to insure minimum standards of quality and some uniformity in the administration of legal services rendered.

(2) Special arrangements to acquaint the service man with the existence of, and to facilitate his efforts to make use of, the remedy.

It might be of some interest to give a short account of the facilities which are now provided in this respect in the British Army, not only because of the general interest which any comparison of legal institutions in the field of civil procedure-so sadly neglected by writers on comparative jurisprudence-must necessarily offer, but also because it can be claimed with confidence that the system in force in the British Army and the Royal Air Force has come very near to a complete realization of Professor Bradway's last two postulates.

The organization of legal advice to poor persons in this country had begun to make great headway already before the outbreak of the war. $^{3}$ While legal assistance in the Courts remained within the narrow limits set by Order XVI of the Rules of the Supreme Court, private

† J. U. Dr. 1927; member of the English Bar (Lincoln's Inn) ; 1937-1939 Leeturerer in Roman Law, Birkbeck College (University of London); now on active service with H. M. Army. Author of The Unification of the Laze of Commercial Arbitration (I938) 24 Trassactions of THE Grotius Soclety I; Commercial Arbitration and the Rules of Law (194I) 4 U. OF Toronto L. J. I; The Problem of $W$ ar Crimes Today (I941) 26 Transactions of THE Grotius Societr; Legal Aid for the Poor, a Study in Comparative Law and Legal Reform (1943) 59 L. Q. REv. 250, and other articles in legal periodicals.

I. Bradway, Lawyers and Morale (1942) gr U. OF PA. L. REv. 233

2. Id. at 235 .

3. The best survey of the existing facilities is JoNes, Frez LEGAz Advice IX Englasd asd Wales. A Report on tite Organization, Method and Future of Poor MAs's LAwYers (prepared for the Executive Committee of Cambridge University Settlement, Camberwell, London) (r940). 
initiative had taken considerable interest in the question of legal advice outside litigation. Poor Man's Lawyer Centres were set up in an increasing number of London Boroughs and provincial towns. Since the outbreak of the war which brought a tremendous increase of small problems of immediate urgency in which members of the public needed guidance, Citizen's Advice Bureaus have been formed all over the country. These Bureaus are under the supervision of the Council of Social Service. They are, of course, not in the first instance called upon to offer legal advice, but deal with the numerous problems of all kinds which worry the average citizen in times of emergency, including, of course, a number of questions of administrative law arising out of the emergency legislation. Some of these Bureaus, however, will also offer legal advice where this is needed and where the support from local legal practitioners has made this possible, which is not everywhere the case. Notwithstanding the existence of these facilities it was, however, soon found that the special needs of the members of the Armed Forces were not sufficiently provided for. It became clear that even the most excellent network of civilian Bureaus could not cope with the special problems which legal advice to serving men presents.

These problems are throughout of an organizational character. There is in this country as good as no separate law dealing with any special problems of the transition from civilian to military life and the impact of this transition on the private rights and liabilities of the individual soldier. There is no equivalent in English law to the American Soldiers' and Sailors' Relief Act of 1940.' Nor is there any need for such special legislation. The Courts (Emergency Powers) Acts 1939 and 1940 and the Liabilities (War Time Adjustment) Act I940 have made liberal provision to assist those who owing to the abnormal conditions created by the war find themselves unable to meet their obligations. The Rent and Mortgage Restrictions Acts which were in force during and after the last war were revived in 1939 and have greatly eased the financial burdens resting upon the shoulders of the poorer part of the population. Finally a War Service Grant scheme is in operation, under which the Ministry of Pensions may assist serving members of His Majesty's Forces by special grants which are additional both to the soldier's pay and to the allowance payable to his family, provided such special grant is required to enable the individual

4. Sce Professor Skilton's article The Soldiers' and Sailors' Civil Relief Act of 1940 and the Amendments of 1942 (1942) 9I U. OF PA. L. REv. 177. A good sumnary of English emergency legislation will be found in the Citizen's Advice Notes published by the National Council of Social Service, Inc of 26 Bedford Square, London IV. C. 2 , which is continuously kept up-to-date on the loose-leaf system. 
to maintain his family and at the same time to meet his existing civilian liabilities. These various enactments appear on the whole to have solved the financial problems arising from the mobilization as far as they concern the life of the individual satisfactory-all the more so as the wives of serving men have, in the overwhelming majority of cases, been able to engage in some kind of full-time or part-time workoften war work-so that notwithstanding the call-up of the husband the joint income of the individual household has not suffered an appreciable loss.

But, as Professor Bradway rightly says, improvements in the law are only one part of the problem. The other task consists in making the benefit of these laws accessible to those for whom they have been created by providing legal advice and, in cases where this is needed, legal assistance in the various Courts administering the law. It was soon found that the existing civilian facilities were insufficient for this task.

Many camps are in places in which no Poor Man's Lawyer Centre is available and a good many are situated in localities where no firm of solicitors is practicing. Journeys to nearby places in which either a Poor Man's Lawyer Centre or a firm of solicitors or at least a Citizens' Advice Bureau can be found are only rarely compatible with the exigencies of the service. Bureaus as well as solicitors' offices will not always be open at those hours at which the serving man may find it possible to attend. The legal profession itself is overworked owing to the fact that many of its members have themselves joined the Forces. A considerable number of Poor Man's Lawyer Centres have had to close down. Costs in the High Court are out of proportion to the soldier's pay and even to the sums which can be paid under a War Service Grant. Contingent fees are not permitted in this country. In addition to all this, many problems have become much more difficult to solve simply as a result of the absence of the men from their homes: what could be settled by a short personal interview with a landlord or former employer or tradesman must now be treated by way of correspondence which not everybody is capable of conducting. And last but not least, the enforced separation of husbands and wives has increased the number of matrimonial disputes of all kinds to such an extent that even the full peace-time strength of legal aid and legal advice organizations would have found it no easy job to cope with them.

This situation could only be remedied from within the Armed Forces themselves. Both those who needed help and those who were 
capable of offering it, are members of the Armed Forces. It was therefore the most obvious course that the Armed Forces themselves should undertake to set up the organization which made it possible for the two to meet so that the assistance could be rendered and received. This is what has actually been done, as far as the Army and the Royal Air Force are concerned. The Navy was presented with special difficulties of an organizational and sociological character which were found impossible to solve, so that the special facilities of legal aid are at present confined to the Army and the Royal Air Force. The basis of the scheme for which the War Office in common with the Lord Chancellor is responsible, ${ }^{\circ}$ is the voluntary and unpaid work of the serving members of the profession. The serving lawyer renders his service to his fellow-soldier on the ground of their common membership in the same fighting force. He receives no compensation from the Army or from the client, nor will his work have any influence on his military status or chances of promotion. But this strictly voluntary and unpaid help is organized and supplemented by an official organization consisting of other serving members of the Forces who devote their full working time to this task and can insofar be considered as paid legal aid workers-although of course their military status is exactly the same as that of any other soldier of the same rank. The scheme is therefore ultimately not of a charitable character. The individual soldier does not receive charity by receiving legal aid. He is being granted a right to receive this assistance as long as the scheme is in being. If there should, in any district, be a lack of volunteers who are willing to render their services, the supplementary organization will step into the breach. Ideologically the scheme must be considered as the socialization of legal aid, made effective-curious as this may sound-by the private initiative of the socially minded members of the profession.

By an Army Council Instruction all soldiers who are qualified barristers or solicitors were asked to volunteer to place their professional skill at the disposal of the authorities. Both the offer and the acceptance are independent of the military rank of those who volunteer as legal advisers. In fact members of the legal profession volunteered and were appointed as legal advisers with complete disregard of their military rank. Some of the legal advisers are senior officers, others are privates. All their work is done in their spare time, although, of course, every due regard will in practice be paid by the Commanding Officers to the fact that this work is being done and where necessary

6. A. C. I. 1398 and the booklet "Free Legal Aid to Members of His Majesty's Ifilitury Forces", issued by the IVar Office (1942). 
due allowance is being made for it in the allotment and arrangement of duties.

The scheme is confined to civil legal problems, including divorce. The following matters are expressly excluded:

I) Claims of one serving soldier against the other.

2) Matters concerning the military status, rights or duties of soldiers, such as discipline, courts-martial, pay, allowances or any other matter which concerns the soldier qua soldier.

3) Criminal law.

None of these restrictions have in practice given rise to any difficulties. It goes without saying that the Army cannot render assistance to one soldier as against the other; that would be contrary to the character of the entire legal aid scheme, as based on the relation of comradeship subsisting between all serving men. Such cases are also comparatively rare and can usually very efficiently be dealt with by the existing Army Welfare Organization whose officers will, in suitable cases, lend their services for the purpose of effecting a friendly settlement. Problems which are within the area of exclusive military judgment must, as Professor Bradway ${ }^{7}$ has rightly said, be left to the orthodox machinery set up by the existing regulations. Interference by the legal aid scheme would be unwarranted, and would be detrimental both to military discipline and to the reputation and universal approval which the scheme is meant to earn from all ranks of the Army. Matters of criminal law are excluded, apparently for the same reason for which many existing civilian legal aid institutions are excluding them from the realm of their activities. The legal advisers are of course free to inform serving men of the existing facilities for legal aid in criminal matters.

The scheme is meant to assist those serving men only who do not possess sufficient resources to employ their own solicitors. The circle of those who can be assisted by legal advice is identical with the circle of those who may receive legal aid in litigation. Everybody who is being advised can thus count upon being assisted in Court where this is necessary. For this reason the scheme is confined to soldiers. up to and including the rank of sergeant, provided the private resources of the individual applicant do not allow him to pay the usual fees of private legal advice. The standard to be adopted in assessing the private resources of an applicant is to be roughly identical with that adopted by 
the Poor Persons' Rule in England ${ }^{8}$ or, in Scottish cases, their Scottish equivalent. ${ }^{\circ}$ Every applicant is required to sign a form in which he asserts that he does not possess means enabling him to employ a solicitor. No inquiries are made from third parties or public authorities but in case of aid in litigation a Statutory Declaration is required concerning the means at the disposal of the applicant. The initial form to be signed by every applicant contains also a clause stating that the applicant agrees that all advice is given to him on the condition that he shall have no right to compensation either against the state or against any of the personnel of the legal aid scheme for any loss or damage arising out of advice or assistance received by him. The latter precaution is obviously justified for without it it might have been difficult to find a sufficient number of volunteers to assist in the operation of the scheme.

The scheme is operated by two different sets of institutions: Legal Advice Bureaus and Command Legal Aid (Civil Affairs) Sections. The former are exclusively staffed by volunteers, while the latter consist of officers and other ranks who administer the scheme as a full time occupation. The Legal Advice Bureaus do, so to speak, the front line work of legal advice. The Legal Aid Sections supervise their work within the district of the Command in which they have been set up, assist them, as far as necessary by individual advice and circular letters on typical problems, secure uniformity of treatment and deal with those matters which may result in proceedings in the High Court. They will also deal directly with any case wherever the applicant for any reason is unable to contact a Legal Advice Bureau.

8. Under the Poor Persons' Rules in England the poor person must not be worth a sum e:cceling $\neq_{50}$ (excluding wearing apparel, tools of trade and the subject matter of the proceedings) or in special cirumstances which are not further defined froo, and his usual income from all sources must not exceed t2 $_{2}$ or in special circumstances $f_{4}$ per week. These limits are generally feit not to be sufficiently gererous. The London Poor Persons' Committee and the London Poor Man's Lawyer Centres assume therefore that "special circumstances" in the sense of these regulations exist in all London cases by reason of travelling expenses from and to work and in view of the fact that the costs of living in London are higher than in other parts of the country. JoNEs, op. cit. supro note 3 , at 10. The provincial committees have, however, shown a less benerolent attitude. Order XVI, rule 233 , now states that serving nembers of His Majesty's Forces are to be considered as poor persons if they cannot "reasonably" afford the costs of the case. This gave the Army authorities 2 somewhat greater latitude which was needed seeing that the pay of a full sergeant and in many cases already that of a coiporal is considerably in excess of $f_{2}$ per week even if the cash payments only are taken into account. The scheme as laid down in the War Office regulations demands that the limits of the Poor Persons' Rules should be taken as the basis of the assessment, but only "roughly" and Legal Advice Bureaus as well as Legal Aid Sections have generally assumed that they are entitled to follow the attitude of the London Committee rather than that of the provincial committees. Notwithstanding the wording of rule $23 a$ there is, however, no replacement of the fixed-limit principle by an elastic principle.

9. Scottish law follows the Continental European system; there are no fixed linits of income or property. The question is left entirely to the discretion of the authorities. 
The Legal Advice Bureaus are formed by units in which personnel with legal qualifications is available. As this is naturally not the case in all units, Bureaus formed in one unit may have to render services to adjoining units, sometimes to a whole garrison or to several adjoining garrisons. The Bureaus are located at any place where legal advice may conveniently be given. If the units do not themselves possess such a room, rooms may be placed at their disposal by one of the Welfare Organizations which are constituting the Council of Voluntary War Work, such as the Y. M. C. A. All advice is to be given under conditions of strict privacy. All communications from and to the Bureaus are considered as strictly confidential in the same way as if they were made by or to a practicing lawyer. The address of the Bureau and the times at which it is open are notified from time to time in the unit orders of the units which are served by the Bureau. In most cases appointments with the legal adviser at the Bureau may also be made by letter or over the telephone.

Applicants receive all services of the Bureau free of charge. They have to pay their own travelling expenses if they visit Bureaus outside the locality at which their own unit is stationed. The number of Bureaus established thanks to the readiness of members of the legal profession to serve is by now so large that these traveling expenses will in all but very rare cases be trifling. The Bureaus work within the limits set by the Solicitors Act 1932, i. e., they must not draft any instrument relating to real or personal estate or legal proceedings with the exception, however, of wills or other testamentary documents, agreements under hand or powers of attorney. The scheme does not supersede the existing legislation; that would have required an Act of Parliament. Cases in which the Bureaus are asked to draft any document which is not covered by the three exceptions to the rule are, however, exceedingly rare. The British soldier's pay book contains a form for making a will which will in most cases be fully sufficient. The number of cases in which the Bureaus are called upon to draft wills providing for contingencies not foreseen in the official form is, however, as experience has shown, not quite negligible.

The authority of the Army or Air Force must, of course, not be used for the purpose of supporting private claims by serving men. For this reason the advisers at the Bureaus are not allowed to write letters to third parties in their own name or in that of the Bureau. On the other hand they may and frequently do furnish to the applicants drafts of such letters as the applicant in his position could reasonably write and the regulations permit the insertion of a statement that the letter 
has been written upon advice received from an Army Legal Advice Bureau. Experience has shown that this is fully sufficient to cover all legitimate needs even in cases in which a lengthy correspondence is required.

In cases in which litigation is not contemplated the applicant will reccive advice immediately from the Bureaus. If the case presents any difficulty or is of special importance or if the adviser owing to local conditions has no access to the necessary reference books he will communicate by letter or telephone with the Legal Aid Section of his Command which will furnish him with the advice-sometimes after having sought and obtained counsel's opinion in cases of particular difficulty or in cases involving foreign law. The Legal Advice Bureau will advise the applicant on the basis of the advice thus obtained. The Bureaus communicate directly not only with the Command Legal Aid Section, but also with any Commanding Officer in the Army or Air Force. Their letters are not required to go through the "official channels". Unit funds are responsible for the traveling expenses of the advisers, for postage, telephone and other clerical expenses.

Some difficulty is experienced in cases in which litigation is intended before the Courts of Summary Jurisdiction and before the County Courts. English Law does not provide for legal assistance to poor persons in these courts. ${ }^{10}$ On the other hand the enforced absence of serving men from their homes makes their representation before these Courts by qualified lawyers even more desirable than under ordinary conditions. Claims for the maintenance of wives and children -legitinate and illegitimate-constitute an appreciable part of the work of the Bureaus. These clains are within the jurisdiction of the Courts of Summary Jurisdiction. Rent Restriction cases fall within the competence of the County Courts. The difficulty is overcome by referring the applicant to a solicitor who is prepared to take the case on either free of charge or-as a rule-against a very modest charge. The task of the Bureaus to find.solicitors who are willing to undertake such work is of course not quite easy. It is, however, facilitated by the existing civilian agencies, such as the Bentham Committee, the head organization of the London Poor Man's Lawyer Centres, and by lists which the Command Legal Aid Sections have prepared for their districts. The requirement of a small fee of one to four guineas rarely presents a difficulty as the serving man is in receipt of regular pay and therefore in a very much better position than many of the applicants of the civilian Poor Man's Lawyer Centres.

10. This is one of the aspects of the present English system which has found very scvere criticism from legal writers, see $c \cdot g$. JACKSON, THE MIACHINERY OF JUSTICE IN ENtil.AND (IO-40) 252 . Joxes, op. cit. supra note 3 , at 55. 
If action before the High Court is contemplated the scheme works as a supplement of and an assistant to the Poor Persons' Committee which under Order XVI of the Rules of the Supreme Court is entitled to grant certificates admitting plaintiffs or defendants to the status of a poor person in the High Court. In such cases the adviser at the Bureau will see the applicant and obtain from him all the information and documents which are at his disposal. The Legal Aid Sections have issued circular letters detailing in a convenient form the kind of information which is required in the more typical cases so that a reasonable amount of uniformity in the statements obtained from the applicants is guaranteed. If the adviser finds that the applicant has a prima facie case he will refer the case with all the material to the Legal Aid Section of the applicant's domicil. Where necessary the Legal Aid Section will arrange for statements to be taken from witnesses either in its own district or in that of any other Section. If the witnesses do not live at the place where the section is stationed, their statements are taken by the legal adviser of the unit nearest to the witnesses' residence to whom a request by the Legal Aid Section detailing the name and address of the witness and the outlines of the case as well as the points on which evidence is required will be sent. All statements thus obtained must of course be voluntary. To make sure that no witness feels himself compelled to give evidence by the mere fact that he is confronted with a lawyer wearing uniform, the statement itself must include the admission that the witness understand that he is giving his evidence voluntarily.

The statement of the applicant himself is given by way of a Statutory Declaration under the Statutory Declaration Act 1835, the equivalent in English law in matters which are not or not yet under litigation, to an affidavit. Under the Armed Forces (Administration of Oaths) Order 1940 serving officers of the Naval, Military and Air Force not below the rank of Lt. Commander, Major or Squadron Leader are entitled to administer oaths and take affidavits and Statutory Declarations from persons subject to the Naval Discipline Act, Military law or the Air Force Act. This Act renders it unnecessary for the serving man to resort to the services of a civilian Commissioner of Oaths. It goes without saying that no fee is payable upon the making of a Statutory Declaration by a member of the Forces before an Officer.

If all the documents are completed, thanks to the cooperation between Legal Aid Section and Legal Advice Bureaus, the papers are sent together with a formal application for legal aid to the Poor Per- 
sons' Committee either of the applicants' home town or, in most cases, to the London Poor Persons' Committee. This Committee, a body appointed by the Law Society, the semi-official organization of the solicitors' branch of the legal profession, and approved by the Lord Chancellor, is according to Order XVI of the Rules of the Supreme Court called upon to decide whether to grant the certificate or not. After the exhaustive preparatory work done by the Army Legal Aid scheme this decision is as a rule very speedily given and in most cases the certificate will be issued as a matter of course. The applicant is, however, required, like every civilian applicant, to deposit a sum of $£_{5}$ with the Secretary of the Committee to meet the out-of-pocket expenses of the conduct of the suit. This requirement which is also embodied in the Rules of the Supreme Court undoubtedly causes in a number of cases difficulties as the applicant will mostly also be required to attend at Court so that in addition to this deposit he has also to find the money for his journey. But again the position of the serving man is better than that of the civilian poor person, because he may and often does receive credit or support from regimental funds and from army charitable organizations, although of course this is not a wholly desirable solution.

The Poor Persons' Committee after having granted the certificate entitling the applicant to the status of a poor person hands the files on to a solicitor who will conduct the case for the applicant free of charge. The solicitor briefs counsel who also is a volunteer working free of charge. The majority of cases, however, are divorce cases and these are dealt with by the Services Divorce Department, a Statesubsidized department of the Law Society, which will in cases of this character perform all the services of a solicitor. Its out-of-pocket expenses are covered by the deposit. The solicitors who do the actual work are employees of the Law Society. Both the Services Divorce Department and the individual solicitor will communicate with the applicant directly, but where a reply to queries is required the applicant may and will, of course, consult his local Legal Advice Bureau which may draft his reply for him or communicate directly with the Services Divorce Department. The applicant is therefore assisted by the Army organization or those who collaborate with it from the start until the completion of his case.

Scotland and the Isle of Man have a legal system which differs considerably from the Common law. In practice this presents as good as no difficulties, as the Legal Aid Section in the Scottish Command is of course staffed by lawyers who are qualified in Scots law, while one 
of the English Command Legal Aid Sections specializes in the law of the Isle of Man. The Channel Islands are unfortunately in enemy hands and cases before the courts of these islands cannot be undertaken. The Scottish Legal Aid Section has assisted the Legal Advice Bureaus in their preparatory work by issuing instructions on the typical problems of Scots law which arise in Army legal aid work.

The scheme does not yet embrace Northern Ireland. Legal Advice Bureaus and Legal Aid Sections can also, of course, not be set up, amongst troops overseas-for obvious reasons. However, Commanding Officers may refer cases arising amongst their men from overseas directly to the London Legal Aid Section and the applicants will receive every advice and assistance which is possible under the circumstances. It may perhaps be possible at a later stage, when large numbers of troops will be in stationary positions overseas, to extend the scheme to these troops.

The scheme has been in operation for over 14 months now. It has been universally recognized as an important social service. It has been favorably commented upon by the national press. What is perhaps more important, it has been made use of to a very large and still growing extent by those whom it is meant to assist. The great bulk of cases are of course of a domestic nature. This is a sociological necessity. The serving man has severed all relations of a purely business character. The longer he has been in the Armed Forces, the more do these civilian business relations recede into the background of his interests. Ex hypothesi the soldier-applicant is poor. $\mathrm{He}$ is therefore not troubled with problens concerning the administration of his property, excepting perhaps the question of his will. The domestic relation is therefore the only one which remains. Unfortunately the isolation of this relation is not accompanied-or not always accompanied-by its intensification. Prolonged absence from home leads too frequently to estrangement. The wives of serving men who are doing war work which brings them in contact with men of all sorts are exposed to temptations. The men in the Army often work in close contact with the Auxiliaries of the women's part of the Forces. Matrimonial ties would have to be a good deal stronger and would have to possess a much sounder ideological fundament than they do today to weather conditions like these without any difficulty. The experiences made in the last war are repeated. The number of divorces is rapidly rising. It has by now reached a stately figure, although it is probably more astonishing that given conditions as they are the figure is not considerably higher. Among those members of the legal profession who are in direct contact with this kind of legal work there is little 
doubt that it is ethically preferable to dissolve a marriage that does not any more hold the spouses together than to keep a tie in being that has become artificial. In so far as it is believed that the speeding-up of divorce proceedings which has been one of the consequences of the introduction of this scheme is a real ethical advantage, especially in those frequent cases in which it enables a new and-one hopes, sounder marriage to be concluded.

The other important service which the scheme offers to the fighting men consists in the protection which it grants him against the little profiteer. It is no rare occurrence that the departure of the head of the family and his entry into the Arny is taken advantage of by shady tradesmen and landlords who will approach the lonely wife on whom the burden of the household now entirely rests with all sorts of totally unfounded claims. In many cases of this character one letter drafted by one of the Legal Advice Bureaus has proved to dissipate by one stroke the clouds of worry and trouble hanging over the soldier and his wife. It goes without saying that the import of such assistance upon the morale of the individual soldier is very considerable.

It is believed that no legal aid scheme of comparable size and intensity has ever been provided in any fighting force. It is probable that no legal advice scheme of equal size has ever existed-including the civilian organizations. It cannot be claimed that the scheme is perfect in any way. That would have required far-reaching changes of the ordinary English law which are impossible at the moment. But it cannot be doubted that it constitutes a very great advance compared to civilian and to pre-war conditions in this country. It is interesting to speculate upon the consequences which this scheme will have for the post-war development of the law of legal aid to the poor. The reform of this branch of our law has been denanded over and over again by legal writers, including authors of very different views in other respects. ${ }^{12}$ That part of the legal profession which is busy with the pen seems to be convinced of the necessity of a reform. But that does not mean that the more silent but more influential part of the profession is of the same opinion. It lies in the nature of things that the men who get the largest briefs and are consequently the leaders of the profession have less opportunity of forming a well-founded opinion of their own upon questions of this nature. The struggling young barrister and solicitor or the academic teacher who attends at the Poor

II. See in addition to those quoted in note 10 supra, e. g. EDwards, The Poor and the Law in 1928 (paper read before the Law Society) (1028) 166 L. T. 233; Mullins, IN Quest of JUSTICE (I931) 386; Keeton, Thic Problem of Law Reform after the IVar (1942) 58 L. Q. REv. 147. See also Cohn, Legal Aid for the Poor, a Study' in Comparatiz'e Law and Legal Reform (July 1943) 59 L. Q. REv. 250. 
Man's Lawyer Centre ${ }^{12}$ is a greater authority on this problem, although, alas, not a more powerful one. One wonders whether the administration of this scheme by many members of the profession with heretofore only a slight or a theoretical knowledge of the actual conditions will not help the cause of reform.

On the other hand large masses of the population have through the functioning of the Army scheme become accustomed to a legal aid service which to this extent and in so convenient a form did not exist in peace time and will, if no preparations are made, not exist after the war has come to an end. Is it too much to hope that the political parties which have so far without exception only taken a very minor interest in this problem ${ }^{18}$ may be roused into activity by the expectation that discontent will arise if facilities are lacking which the men in the Forces have become used to consider as perfectly natural and usual? Or will the lesson be forgotten and will, what is granted now generously and by way of right, again be restricted and be treated as a mere matter of charity?

War. will only in rare cases generate anything good. This war seems to be an exception: it has given birth to a new spirit in this country, a spirit which many are inclined to consider as a complete renaissance. In its way this spirit, if it survives, must be totalitarian too: it will not leave little corners and niches in which the conceptions of a bygone age can linger on. The legal aid worker may therefore be forgiven for nourishing the fond hope that a lasting and substantial improvement of the conditions in his field of work will be one of the immediate results of the new ways of thinking which the unforgettable experience of the war will produce.

12. Cambridge University has for some time past given particular attention to legal aid work. A number of members of the Cambridge Law Faculty serve on the Cambridge Poor Man's Lawyer Centre. Trinity Hall has met the entire costs of the Cambridge House Poor Man's Lawyer Centre, the busiest of the London Legal Aid centres.

13. Recently the Legal Reconstruction Subcommittee of the Haldane Society, a society of barristers and solicitors affiliated to the Labour party, has published 2 report The Law and Reconstruction which deals inter alia also with legal aid to the poor. For a detailed criticism of the scheme proposed by this committee see Cohn, supra note II. 